\title{
Change, Limitations and Transformation - Historical Development and the Impact of European Experience on China's Transformation
}

\author{
Liu Ziwei ${ }^{1,2}$ \\ ${ }^{1}$.Department of History, The Chinese University of Hong Kong, Hong Kong, 999077 \\ 2.Liu Ziwei, female, a postgraduate from Weifang, Shandong, majoring in Comparative and Public History.
}

\begin{abstract}
Many historians argue that the main impetus for the last two hundred years of world history has come from the global political expansion and economic development, however, in this historical development, China and Europe have developed and changed in a reciprocal way. There is no complete opposition or fragmentation in the development of the world and the country, and an in-depth examination of China's transformation in the light of historical developments and the European experience. Consider the limitations of various aspects of the European experience in this process of change in order to think China's development more objectively and intellectually from the perspective of national transformation. An inquiry into the social transformation and future development of modern China can give historical research a contemporary value. In this paper, we analyze the impact of historical development and European experience on China's transformation from the perspective of change, limitation and transformation. Hoping it can give some inspirations and references for history researcher.
\end{abstract}

Keywords: Development in China and Europe; Historical comparison; Experience and limitation

\section{Introduction}

In the book < Transforming China: Historical Change and the Limits of the European Experience>, the Chinese-American scholar Wang Guobin made a comparative study of Chinese and European history from the Ming and Qing dynasties to modern time, and made a comparison with a more objective and fresh approach and perspective on the development of China and Europe. From this work, we recognize the similarities and differences between Chinese and Western societies in terms of economic, political, state and social struggles, as well as recognize the the European experience in the two hundred years of development of the modern world certainly has many advanced features, but its latent limitations also need our attention.

\section{Implications of Historical Development and European Experience for the Study of China's Transformation}

In the comparative study of China's historical development and the European experience, on the one hand, it can help us to understand the reasons for the different development trajectories of China and Europe on the two paths of capitalism and socialism objectively from a broader perspective, thus making China's transformation and development process insist more firmly on socialist path; on the other hand, in a study of the limitations of the European experience and in a comparative study of a series of changes that China has experienced in its historical development, it can also help us to stand at a certain point in time and stage of history and analyze and grasp it with a forward-looking perspective. It is also possible to grasp the reasons behind the historical development and the results of transformation from the characteristics of chance and openness, and thus have a better understanding of contemporary China's transformation, development, but also more objective and scientific speculation and adjustment, the historical wisdom of the role of future development ${ }^{[1]}$. The significance of the historical development and the European experience on China's transformation is not to use the European framework to examine China or the Chinese model to examine Europe, but rather to compare the differences in the way the two have solved historical problems under different social roots, and thus to gain a unique historical experience. It is the most crucial significance of this study to provide value for the development and reform changes in China today ${ }^{[2]}$.

\section{Historical development and the impact of the European experience on China's transformation}

An analysis of the historical changes and transformational development of China from the Ming and Qing dynasties to modern times and an empirical comparison with the European situation reveals that China and Europe have 
certain similarities in historical change, and the shift to a certain time begins to diverge in staging and eventually leads to a China and European countries have embarked on different paths of socialism and capitalism respectively ${ }^{[3]}$. In this long process of historical change, the analysis of China's transformation from an objective, "Eurocentric" point of view. It can be found that there are many influences of historical development and European experience on China, which are analyzed the impact of the European experience on China's transformation from three aspects: economic, political and social struggle, which will help us to understand more clearly the transformation of China and the role of the European experience and have a more comprehensive and in-depth view of the social transformation and development of China in history.

\subsection{Impact on economic development}

Looking back at history, China during the Ming and Qing dynasties and Europe in early modern were very similar in terms of population and resources, and both under the circumstances of unstable agricultural harvest and limited production of raw materials. Both China and Europe are experiencing a prolonged cycle of economic expansion and contraction which gradually accumulated and formed a larger economies under the influence of Smith's power. Up until the 19th century, China and Europe followed a similar pattern of economic development, primarily through the expansion of trade markets, promoting market exchange, division of labour, and the development of more specialised production techniques, which in turn contribute to increased efficiency of production. Such an approach, with the development of trade market size as the root and source of socio-economic development, is all within the scope of the Smith-type dynamic economy ${ }^{[4]}$. However, with the 1860s, the first industrial revolution in England and led to the industrialization of almost all of Europe , Europe gradually freed itself from the limitations between population and agricultural harvests, China and Europe diverged in their economic development, and Europe under the influence of the first time of the Industrial Revolution, the traditional handicraft industry, which used to be based on purely manual power, was gradually replaced by the mechanized factory industry. The socio-economic transition is beginning to take place in Europe, with savings and investment becoming the main theories of power growth, while changes in the economic environment are the important reasons for the sprouting of Chinese and Western capitalism ${ }^{[5]}$. By comparing the sprouting of Chinese and Western capitalism in Table 1 below, we can see more clearly that, in the course of historical change and development, how China and Europe gradually diverged and moved towards different models of social systems, given the same economic conditions as before.

\section{Table 1. Comparison of the infancy of capitalism in China and the West}

\begin{tabular}{|c|c|c|c|}
\hline & & $\begin{array}{l}\text { China in the Ming and } \\
\text { Qing dynasties }\end{array}$ & Modern Europe \\
\hline \multicolumn{2}{|c|}{ Common point } & \multicolumn{2}{|c|}{$\begin{array}{l}\text { All emerged at the end of the feudal period, based on } \\
\text { the development of the commodity economy, and all } \\
\text { were standardized on the emergence of artisanal } \\
\text { factories } \\
\text { They were produced at roughly the same time, in the } \\
\text { 14th-16th centuries. }\end{array}$} \\
\hline \multirow[t]{4}{*}{ Point of difference } & Background & $\begin{array}{c}\text { In the context of an } \\
\text { unprecedented } \\
\text { strengthening of the feudal } \\
\text { dictatorship }\end{array}$ & $\begin{array}{l}\text { Autonomous cities from } \\
\text { the Mediterranean coast }\end{array}$ \\
\hline & Distribution & $\begin{array}{l}\text { Occurs only in a few cities } \\
\text { in the south of China, in a } \\
\text { few industries, and does } \\
\text { not penetrate the } \\
\text { countryside. }\end{array}$ & $\begin{array}{c}\text { It is present in the cities } \\
\text { of many countries and } \\
\text { has reached out to rural } \\
\text { areas. }\end{array}$ \\
\hline & $\begin{array}{l}\text { Commercial } \\
\text { capital }\end{array}$ & $\begin{array}{l}\text { The germ of Chinese } \\
\text { capitalism was only mainly } \\
\text { within the handicraft } \\
\text { workshop, in which } \\
\text { commercial capital mostly } \\
\text { played a minor role. }\end{array}$ & $\begin{array}{l}\text { The sprouting of } \\
\text { capitalism in Western } \\
\text { Europe produced two } \\
\text { paths, with commercial } \\
\text { capital playing a huge } \\
\text { role. }\end{array}$ \\
\hline & $\begin{array}{l}\text { Development } \\
\text { environment }\end{array}$ & $\begin{array}{l}\text { Obstructed by a corrupt } \\
\text { feudal system and lack of } \\
\text { support from multiple } \\
\text { sources, including finance, } \\
\text { technology, labour and }\end{array}$ & $\begin{array}{l}\text { The opening of new } \\
\text { voyages and the } \\
\text { germination of } \\
\text { capitalism under colonial } \\
\text { plunder and mercantilist }\end{array}$ \\
\hline
\end{tabular}




\begin{tabular}{|c|c|c|c|}
\hline & Outcome & $\begin{array}{c}\text { Chinese society has not } \\
\text { been transformed and has } \\
\text { not embarked on the } \\
\text { capitalist path. }\end{array}$ & $\begin{array}{c}\text { The budding and rapid } \\
\text { development of } \\
\text { capitalism and its } \\
\text { contribution to the } \\
\text { collapse of the feudal } \\
\text { system, which gradually } \\
\text { established the capitalist } \\
\text { system }\end{array}$ \\
\hline
\end{tabular}

Through the above comparison, we can see that the dynamics of economic change in China and Europe are similar, but before the 19th century, due to the impact of the British Industrial Revolution, the economies of China and Europe have begun to part ways, Europe in the change and development has gradually stepped into the urban mechanized industrialization, while China still maintain the development of agricultural handicrafts.

With regard to the economic changes in China and Europe, scholars such as Huang Zongzhi have argued that population growth leads to resource scarcity and implosion. However, when analyzed in terms of the relationship between rural industrialization and demographic change, both Europe and China were in a phase of population growth before the 19th century, and factors such as population and resource allocation were not the main factors of motivation that led to the industrial expansion in Europe and China. At that time, Europe had limited resources, so systems such as primogeniture and separate marriages were adopted to ease population pressures, while in the process of rural industrialization, the resources available for survival through market exchange and division of labour increase, thus breaking the old reproductive system and leading to population growth ${ }^{[6]}$. At the time, China was dominated by the extended family model, although marriage did not depend on separation and unrestricted fertility led to the Malthusian potential for a crisis, but because of China's adoption of rural industrialization and an environment where subsistence resources are guaranteed, population growth remains being promoted. Europe outpacing China's development is largely as a result of the technological explosion brought by the discovery of the New World, the exploitation of fossil energy sources and the Industrial Revolution. And China attempted to maintain a social model based on a smallholder economy, which constrained the development of both rural crafts and industry.

\subsection{Impact on the political path}

On the political front, there are also significant differences between Chinese and European development. From the differences in politics and state formation between China and Europe, we can gain more insight into the transformation of nations. Table 2 below shows the contrast between the Chinese state and the European state. We can see the differences between nation-states and agricultural empires in political construction challenges, national capacity and commitment.

Table 2. Comparison of differences between Chinese and European countries

\begin{tabular}{|l|l|l|}
\hline & Ancient China & Modern Europe \\
\hline $\begin{array}{l}\text { Political construction } \\
\text { challenges }\end{array}$ & $\begin{array}{l}\text { Effective control of minority order } \\
\text { in and around the country }\end{array}$ & $\begin{array}{l}\text { Threat of competition from internal } \\
\text { political entities }\end{array}$ \\
\hline $\begin{array}{l}\text { National control } \\
\text { capacity }\end{array}$ & $\begin{array}{l}\text { As the social structure becomes } \\
\text { more complex civil officials } \\
\text { gradually lose control over the } \\
\text { distribution of land and the } \\
\text { management of market affairs. }\end{array}$ & $\begin{array}{l}\text { Building bureaucracies for the } \\
\text { purpose of centralizing taxes, } \\
\text { manpower and resources }\end{array}$ \\
\hline $\begin{array}{l}\text { Obligations } \\
\text { undertaken }\end{array}$ & $\begin{array}{l}\text { Maintaining the smallholder } \\
\text { peasantry as an important social } \\
\text { subject, with the general welfare as } \\
\text { the dominant State policy in order to } \\
\text { obtain the legitimate rights of the } \\
\text { royal family. }\end{array}$ & $\begin{array}{l}\text { The political structure and ideology, } \\
\text { acting as checks and balances on } \\
\text { each other and a greater affirmation } \\
\text { of individual rights. }\end{array}$ \\
\hline
\end{tabular}

China and Europe went through different processes in the formation of their states. There were differences in political organization between China and Europe before the formation of the state. Whereas China essentially did not have religious institutions or aristocratic groups similar to the European aristocracy, the Chinese political tradition and political pattern was unified early, which ensured the establishment of China as a vast empire of harmony and 
unity $^{[7]}$. This led to the fact that while the development of both China and the smaller European states was accomplished through territorial expansion, the two ended up differently, with Europe in the development gradually led to a multinational system, while China developed into a major unified state ${ }^{[8]}$.

Through the contents of the above table, we can recognize that China and Europe have faced different political environment and national formation environment. Material welfare, moral preaching and coercive means are the three ways of maintaining social order and consolidating the authority of the State, in which China and Europe began to differ. Under different political logics, two distinct processes of state formation emerged in China and Europe $^{[9]}$.

\subsection{Impact of social struggle}

The forms of social struggle that China and Europe have faced in the development of historical change are similar, including food riots, anti-tax campaigns, and the Revolution. Through Table 3 below, we can see the differences in the comparison of social struggles in the development of historical change between China and Europe. These differences were also important influences in China's subsequent failure to embark on a capitalist society and to part ways with European social development.

Table 3. Comparison of social struggle in the development of historical changes in China and Europe

\begin{tabular}{|c|c|c|c|}
\hline & Food riots & Tax protest & Revolutions \\
\hline Chinese & $\begin{array}{l}\text { Diversification of the } \\
\text { agricultural economy } \\
\text { formed into a commercial } \\
\text { food trade, with national } \\
\text { and local storage of food } \\
\text { and fulfilment of food } \\
\text { commitments to the } \\
\text { population, but with a loss } \\
\text { of national capacity to } \\
\text { mobilize and organize } \\
\text { resources and the risk of } \\
\text { food riots }\end{array}$ & $\begin{array}{l}\text { The anti-tax movement } \\
\text { organized by the rural elite, } \\
\text { clan organizations, local } \\
\text { secret societies, etc., } \\
\text { petitioning and campaigning } \\
\text { were the main forms of } \\
\text { resistance, but they did not } \\
\text { form a force that could } \\
\text { compete with the State }\end{array}$ & $\begin{array}{l}\text { Peasants played an } \\
\text { active role and } \\
\text { multiple regimes } \\
\text { emerged, but the } \\
\text { people did not } \\
\text { emphasize the spirit of } \\
\text { "freedom, equality and } \\
\text { fraternity", and the } \\
\text { revolutionary ideology } \\
\text { and culture lacked } \\
\text { cohesion. }\end{array}$ \\
\hline European & $\begin{array}{l}\text { The social structure } \\
\text { determines the free market } \\
\text { circulation of food }\end{array}$ & $\begin{array}{l}\text { The aristocratic elite, in their } \\
\text { own self-interest, suppress } \\
\text { the power of the state and } \\
\text { form a representative system } \\
\text { of political participation, } \\
\text { with tax resistance directed } \\
\text { at the central government. }\end{array}$ & $\begin{array}{l}\text { Elites cooperate, } \\
\text { farmers play a } \\
\text { negative role }\end{array}$ \\
\hline
\end{tabular}

Through the above comparison, it can be concluded that there are many differences between China and Europe in the way, content, and main force of social struggle in their historical development, and that the key for modern China to achieve revolutionary success and development is to avoid government intervention, while Europe uses the organization and guidance of the government.

\section{Reflections and insights on China's social transformation based on the European experience}

In the study of The history of China and Europe, the academic circle of history has always maintained a very intense academic discussion on the modern transformation of its economy and society. For a long time, China has been used as a reference point for Europe and the West: on the one hand, academics believe that China is very different from the Western world in many aspects of its development; on the other hand, many history scholars believe that China must undergo a historical process of change and development roughly similar to that of the West in order to achieve the modern transformation of its economy and society.

For a long time, the traditional view in the study of world history was that the process of transformation and development of modern European societies was the only scientific and The right path, China's modern economic and social transformation and development process, if not influenced and modeled by Europe and other Western societies, it will take a very long period of time. When the Californian School emerged, which was mainly concerned with the economic history of China, it placed China in the context of the changes of world history. It is only through research and analysis of China's economic and political ties with the outside world that we can be more objectively and scientifically highlights the importance of Chinese history in the changes of world history, and also makes use of the 
bi-directional approach of space and time to make a comparison of the reciprocal development paths between China and the West ${ }^{[10]}$. This comparative study can give us a deeper understanding of the differences between China and the West in their historical development, allowing us to have a more rational and scientific thinking on the path of "modernization". In today's economic and political developments and games in China and the West, we also need to pay more attention to economic changes, ideology, political culture and so on. Only through this way, can we more effectively maintain national stability and progress and place China on the current of world history.

\section{Conclusion}

In summary, from the perspective of history, in a series of historical changes, due to the many differences between the imagination of many people in China about Europe and the reality of Europe, we need to explore the characteristics of China's historical development from the perspective of objective comparison in order to learn from history and apply it to the development of China today.

\section{REFERENCES}

[1] Li Bozhong. "Looking at each other is never boring": Review of Wang Guobin's "Transforming China: Historical Changes and the Limits of the European Experience"[J]. Historical Theory Research,2000(02):148-158.

[2] Xia Deming, He Weihua. China's Rise, the European Experience and the New World Patterns[J]. Marxism and Reality,2018(01):95-102.

[3] Mei Junjie. The European Experience and China's Revelation-After translation of The Historical Experience of European Development[J]. Social Observation,2015(04):76-77.

[4] Wang De. The Lack of Logical Necessity in Historiographical Latitude Considerations-Reading Wang Guobin's Transforming China: Historical Changes and the Limits of the European Experience [ J]. Frontiers,2013(05):52-54.

[5] Li Bozhong. "Looking at each other is never boring": A review of "Transforming China: Historical Changes and the Limits of the European Experience" by Wang Guobin[J]. Historical Theory Research,2000(02):148-158.

[6] Wang Liyong. The European Experience of Free Trade Port Construction and Development[J]. People's Forum Academic Frontiers, 2019(22):16-22.

[7] Shi Jiayou, Pang Weiwei, Liu Zhongxuan. Civil Code: Chinese Characteristics and European Experience Overview of the 2019 China-EU International Symposium on Civil Code[J]. Journal of Shandong Judges Training College, 2019(5):107-115.

[8] Li Linlin, Wang Jingxin. The basic theory of sustainable development in mountainous regions, European experience and inspiration[J]. Journal of Northwest Agriculture and Forestry University of Science and Technology: social science edition, 2018, v.18; No.118(04):40- 48.

[9] Wang Hao Chen, Li Shu Qin. European artificial intelligence development and its inspiration to China[J]. China Business and Economics Review (Chinese), 2019.

[10] Jin Yonghua, Fan Shanshan, Liu Om. Experience and inspiration from the development of SME clusters in Europe[J]. Telecommunication Network Technology, 2018, 000(012):56-60. 